\title{
HIGH SOLID ANAEROBIC DIGESTION OF MUNICIPAL SOLID WASTE
}

\author{
Sunil Kumar ${ }^{I}$ \\ Somnath Mukherjee ${ }^{2}$ \\ Sukumar Devotta \\ ${ }^{1} N E E R I$, India \\ ${ }^{2}$ Jadavpur University, India
}

\begin{abstract}
Anaerobic digestion (AD) is viewed as an attractive method for waste stabilization prior to landfills as pre-treatment to reduce significant pollution load to the environment. Optimizing anaerobic digestion process aims to maximize organic waste conversion to biogas at short digestion period. The optimization of high solid concentration of MSW in a laboratory scale reactor was carried out to know the maximum biogas production yield.
\end{abstract}

This paper presents the findings of the study on high solid AD process in single which involves enhanced pre-stage (hydrolysis and acidification) and methane phase.

\section{KEYWORDS}

Municipal solid waste; Acidification; Biogas; Recirculation; Alkaline; Acid treatment.

\section{INTRODUCTION}

Unmanaged pollutants from organic farm waste, industrial and municipal solid waste (MSW) degrades the environment and methane emitted from their decomposition contributes to global climate change [1]. Under modern environmental regulations in general and MSW (Management and Handling) Rules, 2000 promulgated by MOEF, Govt. of India in particular, these wastes are becoming difficult to disposed off using traditional means.

There are various technologies for MSW at Global level. However, in India, open dumping is commonly practiced. The huge quantity of MSW generated is mostly disposed off on land without adapting any precautionary measures. This results in contamination of air and water media as well as influences the health of the society $[2,3]$. Though landfill sites are the sources of methane, the landfill gas needs to be purified to increase the methane concentration. Moreover, methane can be recovered for a limited period of time depending upon the life of the landfill site, the quantity of waste dumped at a particular site, and the methane potential of the dumped waste [4]. Thus, the sanitation problem contributed by MSW is alarming and needs immediate attention on priority basis. Lands are becoming scarce for disposal of waste, which pressurizes to look for integrated approach for MSW management. Also, due to an increasing awareness of economic and environmental cost of conventional landfilling, recent interest is to develop the technologies that accelerate the degradation of the organic fraction of MSW. One option is to digest the organic fraction prior to landfilling, or preserve landfill space by accelerating the decomposition of the organic 
fraction within the landfill. Composting, one of the processing options, is being used in many of the municipalities in India. Inferior quality of compost and high cost has resulted in lowmarket demand. Hence biomethanation of MSW has drawn special attention of the researchers, stakeholders and policy makers. The Government of India has announced a national policy to promote and provide financial support to waste based power projects [5]. $\mathrm{AD}$ has been up to now essentially applied to wastewater management [6, 7]. However, anaerobic processing of organic solid waste fits in well with the new requirements for waste management. In connection with the utilization of renewable energies and the rising relevancy of climate protection, it can be affirmed that $\mathrm{AD}$ for the treatment of MSW has a high potential for future development. AD for wastewater is being practiced since long back when $\mathrm{AD}$ was mainly aimed as a treatment alternative. For MSW, it is processing option and it is better to considered as biomethanation.

The biomethanation process can be carried out both in a single step as well as two steps. In a single step process, the biomethanation is carried out in a single reactor. The present investigation is aimed to study the performance of innovative single stage high solid digestion (SSHS).

\section{MATERIALS AND METHODS}

MSW was obtained from Laxminagar zone of Nagpur Municipal Corporation, India. About $50 \mathrm{~kg}$ of MSW samples were collected from five wards in the Lamminagar zone. These were mixed thoroughly. Sample for experiment was drawn on the basis of quartering technique. The physical characterization of MSW was done by separating one quarter. After that, inerts such as plastics, metals and glass items were separated manually. No further preprocessing of MSW was done. This constitutes the base material for drawing samples for chemical characterization as well as for conducting various experiments. The physical and chemical characteristics of the wastes are presented in Tables 1 and 2. Laboratory-scale unit (called as a set from now onwards) consists of glass aspirator bottle of suitable capacity (such as $2 \mathrm{~L}$ or 5 $\mathrm{L}$ ) as reactor, another glass aspirator bottle of suitable size (such as $1.5 \mathrm{~L}$ or $3 \mathrm{~L}$ ) for biogas filled with acidified brine solution along with a conical flask of suitable capacity to collect displaced brine solution. Suitable arrangement for $\mathrm{pH}$ electrode was provided with each set. The schematic of a series of single phase experimental set-up is shown in Figure 1.

Initially, batch studies were carried out in aspirator bottles of different capacity to select essential factors influencing the SSHS approach development with emphasis on total solid concentration, $\mathrm{C} / \mathrm{N}$ ratio, and temperature.

\subsection{Methods for chemical characterization of MSW samples}

The chemical analysis of MSW samples was carried out as per Standard Methods. BIS No. 9234/1979. 
Table 1. Physical composition of MSW.

\begin{tabular}{ccc}
\hline Sl. No. & Constituent & Percent by mass \\
\hline 1 & Coarse Organics & 48.00 \\
\hline 2 & Paper & 7.17 \\
\hline 3 & Plastics & 4.50 \\
\hline 4 & Coconut & 1.93 \\
\hline 5 & Rubber/Leather & 4.20 \\
\hline 6 & Metals & 1.95 \\
\hline 7 & Glass & 1.86 \\
\hline 8 & Rags (textile) & 6.89 \\
\hline 9 & Fine Organics, Earth and Ash & 20.00 \\
\hline 10 & Stones, Bricks, etc. & 3.50 \\
\hline
\end{tabular}

*Components removed from laboratory experiments

Table 2. Chemical composition of MSW.

\begin{tabular}{lll}
\hline SI. No. & Parameters & Values \\
\hline 1 & Moisture content & $35.0 \%$ \\
\hline 2 & $\mathrm{pH}$ & 6.5 \\
\hline 3 & Loss on ignition & $64.70 \%$ \\
\hline 4 & Carbon & $37.53 \%$ \\
\hline 5 & Nitrogen & $1.10 \%$ \\
\hline 6 & Phosphorous & $0.60 \%$ \\
\hline 7 & Potassium & $0.75 \%$ \\
\hline 8 & C/N Ratio & 34.12 \\
\hline 10 & Calorific value & $800 \mathrm{kcal} / \mathrm{kg}$ \\
\hline
\end{tabular}

* All values except moisture content are on dry weight basis.

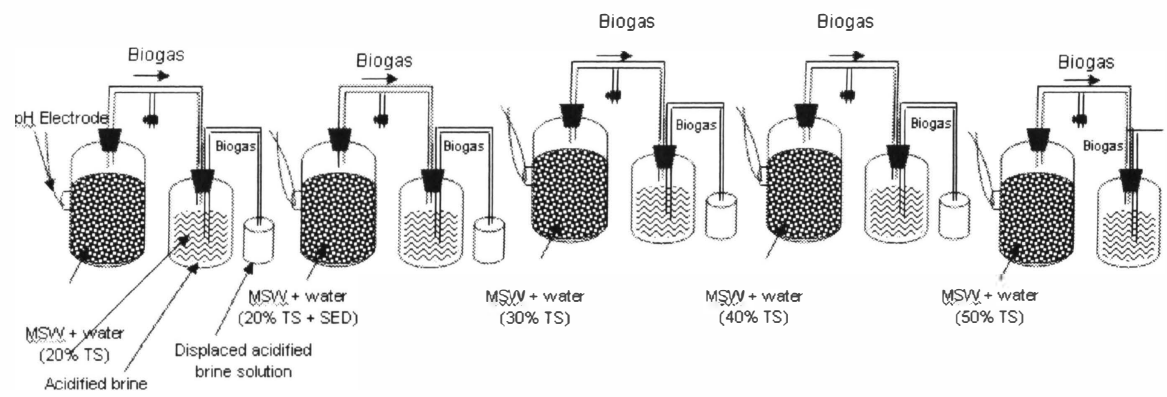

Figure 1. Schematic of a series of single phase experimental set-up. 


\subsection{Effect of total solid concentrations}

In different glass containers, total solid concentrations from $20-50 \%$ were prepared. Desired total concentrations were prepared considering initial moisture content in MSW and accordingly additional water was mixed or sun-dried samples were taken. Here, no pretreatment or pre-seeding was done and experiments were carried out at prevailing room temperature.

The experiments were conducted in five sets of bottle of $2 \mathrm{~L}$ capacities. In the first set, $450 \mathrm{~g}$ sun-dried MSW was mixed with $1600 \mathrm{~mL}$ of tap water (having a total solid concentration of approximately $20 \%$ ) and it was ensured that the container was in air tight condition. In the second, third, fourth sets, $590 \mathrm{~g}, 820 \mathrm{~g}$ and $700 \mathrm{~g} \mathrm{MSW}$ was mixed with $1376 \mathrm{~mL}, 1230 \mathrm{~mL}$ and $700 \mathrm{~mL}$ of tap water with a total solid concentration of 30,40 and $50 \%$ and kept in separate $2 \mathrm{~L}$ glass bottles ensuring air tight condition. The biogas yield was observed by displacement of acidified saturated brine solution. The experiments were conducted at room temperature $\left(29-31^{\circ} \mathrm{C}\right)$.

Each container was provided with a $\mathrm{pH}$ electrode to enable to observe $\mathrm{pH}$ variation inside the mixture in the containers. Gas onset and total quantity of gas from each set was monitored and the yield of biogas was calculated for one $\mathrm{kg}$ of VS.

\subsection{Effect of pre-seeding}

To study the effect of pre-seeding the MSW, experiment was performed with solid concentration of $20 \%$. For this, in the one set, $450 \mathrm{~g}$ sun-dried MSW was mixed with 1600 $\mathrm{mL}$ of tap water with a total solid concentration of approximately $20 \%$ and was filled and ensured that the container is in air tight condition. In the another set, $450 \mathrm{~g}$ sun-dried MSW was mixed with $1200 \mathrm{~mL}$ of tap water along with $400 \mathrm{~mL}$ of liquid culture from the operating digester (corresponding to $5 \%$ seed) thoroughly mixed with the sample. In this set also, the total solid concentration was around $20 \%$. Each container was provided with a pH electrode to enable to observe $\mathrm{pH}$ variation inside the mixture in the containers Gas onset and total quantity of gas from each set was monitored and the yield of biogas was calculated for one $\mathrm{kg}$ of VS.

\subsection{Confirmation of optimum total solid concentrations}

After selecting the suitable optimum total solid concentrations, the experiments were being further repeated using 5 litre glass reactors, which were also provided with $\mathrm{pH}$ electrodes. The studies were conducted using 40,50 and $60 \%$ total solids concentration.

In these experiments, $1200 \mathrm{~g}, 1500 \mathrm{~g}$ and $1800 \mathrm{~g}$ of MSW are mixed with $1800 \mathrm{~mL}, 1500 \mathrm{~mL}$ and $1200 \mathrm{~mL}$ of tap water to make total solid concentrations of approximately 40,50 and $60 \%$ respectively in a $5 \mathrm{~L}$ bottle ensuring airtight condition under controlled conditions with a temperature of $29-31^{\circ} \mathrm{C}$. The biogas yield was observed by displacement of acidified saturates brine solution.

\subsection{Effects of $\mathrm{C} / \mathrm{N}$ ratio}

The experimental set for $50 \%$ total solid concentration, which gives maximum biogas yield during the experiment period, was selected for further study with varying $\mathrm{C} / \mathrm{N}$ ratio. The experiments were conducted by selecting appropriate $\mathrm{C} / \mathrm{N}$ ratios (between 20-60) in $2 \mathrm{~L}$ reagent bottles. 
This run pertains to the effect of different $\mathrm{C} / \mathrm{N}$ ratios. In the first set, for the adjustment of $\mathrm{C} / \mathrm{N}$ ratio of 20, $500 \mathrm{~g}$ of $\mathrm{MSW}$ was mixed with $28.30 \mathrm{~g} \mathrm{KNO}_{3}$ dissolved in $500 \mathrm{ml}$ tap water. For preparing $\mathrm{C} / \mathrm{N}$ ratio of $30,500 \mathrm{~g}$ of $\mathrm{MSW}$ was mixed with $10.9 \mathrm{~g}$ of $\mathrm{KNO}_{3}$ dissolved in 500 $\mathrm{mL}$ of tap water. In the third set, $500 \mathrm{~g}$ of MSW was mixed with $500 \mathrm{~mL}$ of tap water maintaining the $\mathrm{C} / \mathrm{N}$ ratio of 43.5 . In the fourth set, $500 \mathrm{~g}$ of MSW was mixed with $123.5 \mathrm{~g}$ of cardboard and $500 \mathrm{~mL}$ of tap water adjusting the $\mathrm{C} / \mathrm{N}$ ratio of 50 . In the last set, $377 \mathrm{~g}$ of MSW was mixed with $123.5 \mathrm{~g}$ of cardboard and $2.18 \mathrm{~g}$ of $\mathrm{KNO}_{3}$ dissolved in $500 \mathrm{~mL}$ water with the adjustment of $\mathrm{C} / \mathrm{N}$ ratio of 60 . The biogas yield was observed by displacement of acidified saturated brine solution. The experiments were carried out under controlled conditions at a temperature of $29-31^{\circ} \mathrm{C}$. Another set was also repeated at various $\mathrm{C} / \mathrm{N}$ ratios under ambient room temperature.

\subsection{Effects of temperature}

To study the effect of temperature, one run of experiments were carried out at various $\mathrm{C} / \mathrm{N}$ ratios under controlled conditions at a temperature of $29-31^{\circ} \mathrm{C}$. Another run was also repeated at same $\mathrm{C} / \mathrm{N}$ ratios under ambient room temperature.

\section{RESULTS AND DISCUSSION}

The $\mathrm{pH}$ data in a single phase shows that initially $\mathrm{pH}$ of the mixture is in between 6.5 to 7 but after 15-20 days, the $\mathrm{pH}$ value get decreases because of the production of VFAs by indigenious microorganisms present in the MSW which converts the soluble carbonaceous matter. During 20-25 days, $\mathrm{pH}$ values are between 4.0 to 5.5 because of the accumulation of VFA mostly acetic acid. After 25-32 days, the $\mathrm{pH}$ value increases because of the degradation of the VFA into biogas by the methanogenic bacteria developed in the container. During 3235 days again, the $\mathrm{pH}$ value get decreases which may be due to the production of VFA, which is not sufficient to activate the methanogenic microbes present in the system and hence it does not yield biogas anymore.

The $\mathrm{pH}$ data also indicates that higher the total solid concentration, lower the $\mathrm{pH}$ (less than 5.5) because it contains higher soluble carbonaceous matter ultimately gives high volume of biogas. But, lower total solid concentration $(20 \%$ and $30 \%)$ gives higher $\mathrm{pH}(>5.5)$ because of containment of less amount of soluble carbonaceous matter and hence the biogas yield is less.

The experiments reveal that the biogas production starts at around 10 days after filling the waste in the container. The biogas quality generated in containers with $20 \%$ and $50 \%$ of total solid concentration is more compared to $30 \%$ and $40 \%$ total solid concentration. 


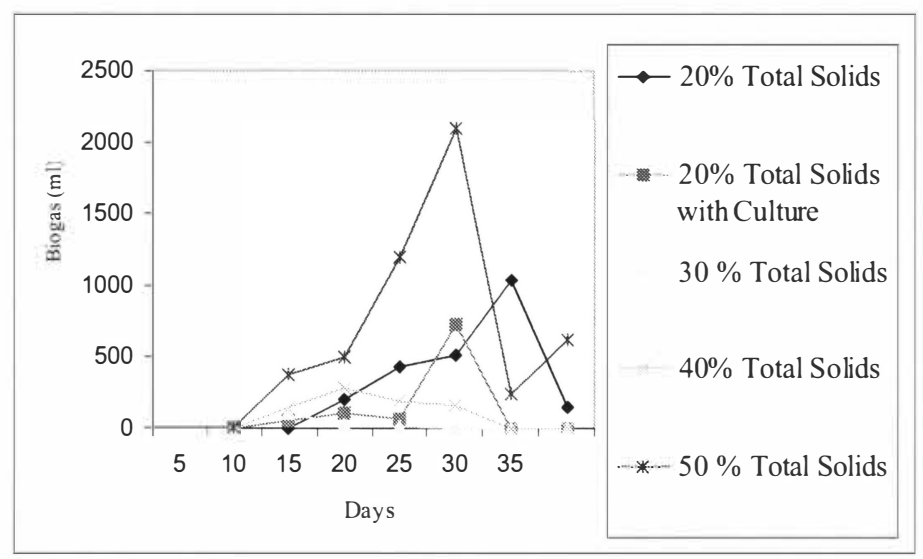

Figure 2. Biogas production under varying concentration.

The results indicate that without culture addition, methanogenic activity takes place. Figure 2 indicates that the biogas quantity is more for 20 and $50 \%$ solid than for $20 \%$ with culture.

It was confirmed that MSW without preparation is suitable for biomethanation. SSHD is feasible, which may prove beneficial for developing for commercial application. MSW with total solid concentration of $50 \%$ gives better performance at $29-31^{\circ} \mathrm{C}$. Similarly, MSW with $20 \%$ total solid concentration gives more biogas yield than $30-40 \%$ total solid, which is less compared to $50 \%$ total solid concentration. The addition of seed (culture) is not necessary. The $\mathrm{pH}$ trends are initially near 7.0 which later decreases to 5.6.Thus, pre-processing of MSW and addition of culture are not obligatory.

\section{REFERENCES}

[1] Fricke, K., Heike, S.A., Rainer, W.B., 2005. Comparison of selected aerobic and anaerobic procedures for MSW treatment, Waste Management, (In Press).

[2] Cecchi, F., Traverso. G., Cescon, P., 1986. Anaerobic Digestion of organic fraction of municipal solid wastes - performance, The Science of the Total Environment, 56, 183197.

[3] Cecchi, F., Traverso. G, J., Mata-Alvarez, J., Zaror, C., 1988. State of the Art of R\&D in the anaerobic digestion of municipal solid waste in Europe, Biomass, 16, 257-284.

[4] Estimates of US biomass energy consumption 1992, May 1994 (tonto.eia.doc.gov)

[5] Proceedings of the first workshop on National Master Plan for development of waste-toenergy, June 12, 2000, New Delhi.

[6] Nopharatana, A., Clarke, A.W.P., Pullammanappallil, P.C., Silvey, P.B., Chynoweth, D.P.C., 1998. Evaluation of methanogenic activities during anaerobic digestion of municipal solid waste, Bioresource Technology, 64,169-174.

[7] Laclos, D.H.F., Desbois, S., Saint-Joly, C., 1997. Anaerobic digestion of municipal solid organic waste: Valorga full-scale plant in Tilburg, The Netherlands, Water Science and Technology, 36 (6-7); 457-462. 